\title{
Manajemen Personalia Lembaga Pendidikan Islam (Studi di Madrasah Ibtidaiyah NW No.1 Boro' Tumbuh)
}

\author{
Muhammad Zulkifli \\ Pendidian Guru Madrasah Ibtidaiyah Fakultas Tarbiyah \\ IAI Hamzanwadi NW Lombok Timur \\ Jln. Utama Mataram - Lb. Lombok Km. 45 Anjani - Suralaga Lombok Timur NTB \\ Korespondensi Penulis: muhzulkifli23I0@gmail.com
}

\begin{abstract}
ABSTRAK
Kata Kunci : Manajemen Personalia dan Lembaga Pendidikan Islam.

Penelitian ini menjelaskan tentang gambaran tentang pelaksanaan Manajmen Personalia Lembagan Pendidikan Islam, yang dalam ini penulis mempokuskan di Madrasah Ibtidaiyah Swasta No.I NW Boro' Tumbuh, yang berlokasi di Jalan Simpang Kulur Desa Tumbuh Mulia Kecamatan Suralaga Kabupaten Lombok Timur. Penelitian ini menggunakan jenis penelitian lapangan (field research) dengan pendekatan yang pakai adalah pendekatan kualitatif. Adapun teknik pengumpulan data yang digunakan antara lain : in-depth interviewing, observasi dan dokumentasi. Hasil penelitan pada tulisan ini, termuat beberapa hal, antara lain : I) Penerapan Manajemen Personalia di MI NW No.I Boro' Tumbuh, 2) Perencanaan Pegawai di MI NW No.I Boro' Tumbuh, 3) Rekrutmen Pegawai di MI NW No.I Boro' Tumbuh, 4) Meningkatkan dan Pengembangan Pegawai di MI NW No.I Boro' Tumbuh, 5) Promosi dan Mutasi di MI NW No.I Boro' Tumbuh, 6) Pemberhentian Pegawai di MI NW No.I Boro' Tumbuh, 7) Penilaian Pegawai di MI NW No.I Boro' Tumbuh, 8) Kompensasi di MI NW No.I Boro' Tumbuh, dan 9) Problem-problem yang dihadapi di MI NW No.I Boro' Tumbuh dalam menerapkan sistem manajemen
\end{abstract}

\section{Pendahuluan}

Kemajuan sebuah organisasi tergantung pada sejauh mana peranan manajemennya. Oleh karena itu, Setiap Organisasi harus memiliki menejemen yang baik dalam rangka mencapai berbagai tujuan tertentu. Dalam manajemen terdapat padanya personilpersonil yang akan menggerakakan kepentingan organisasi secara optimal, dengan menyumbangkan segenap kemampuannya untuk kepentingan organisasi. Dengan demikian manajemen merupakan faktor dominan dalam kemajuan organisasi.

Sebagai wujud preventif bagi para pemerhati kelembagaan pendidikan, kemampuan atau ketidak mampuan dalam pengelolaan manajmen personalia terdapat beberapa hal yang memungkinkan bisa terjadi terhadap kelembagaan tersebut (sekolah/madrasah), antara lain : I) Ada sekolah/madrasah yang pada mulanya mengalami kemunduran, kemudian bisa maju dengan pesat, 2) ada sekolah/madrasah yang kemudian mengalami kemunduran, 3) ada sekolah/madrasah yang awalnya maju dan tetap maju, dan 4) ada sekolah/madrasah yang tidak pernah maju-maju.

Madrasah Ibtidaiyah NW No.I Boro' Tumbuh yang terletak di Desa Tumbuh Mulia Kecamata Suralaga Kabupaten Lombok Timur. Tepatnya di Jln. Simpang Kulur Desa Tumbuh Mulia. Merupakan salah satu Madrasah Ibtidaiyah yang terbaik sehingga sampai saat ini ditunjuk sebagai Ketua Kelompok Kerja Madrasah (KKM) MI di Kecamatan Suralaga.

Karena itulah penulis memandang perlunya penelitian yang berjudul "Manjamen Personalia Lembaga Pendidikan Islam (Studi di Madrasah Ibtidaiyah NW No.I Boro' Tumbuh)”. Adapun rumusan masalah dalam penelitian ini antara lain : I) Bagaimana penerapan manajemen personalia di Madrasah Ibtdaiyah NW No.I Boro' Tumbuh ?, 2) Faktor apa saja yang mempengaruhi penerapan manajemen personalia di Madrasah Ibtidaiyah NW No.I Boro' Tumbuh ?. 
pada mulanya mengalami kamajuan pesat., Sedangkan tujuan penelitiannya antara lain : I) untuk mengetahui bagaimana penerapan manajemen personalia di Madrasah Ibtidaiyah NW No.I Boro' Tumbuh, 2) untuk mengetahui faktor apa saja yang mempengaruhi penerapan manajemen personalia di Madrasah Ibtidaiyah NW No.I Boro' Tumbuh.

\section{Metode}

Jenis penelitian ini adalah penelitian lapangan (Field Research), yakni penelitian yang dilakukan dengan tujuan langsung kelapangan untuk menggali dan meneliti data yang berkenaan dengan efektivitas penerapan menejemen personalia dan Faktor apa saja yang mempengaruhi penerapan manajemen personalia di Madarasah Ibtidaiyah NW No.I Boro' Tumbuh Desa Tumbuh Mulia Kecamatan Suralaga. Penelitian ini dilakukan pada bulan Februari 2018. Adapun Pendekatan yang digunakan dalam penelitian ini adalah pendekatan kualitatif, yakni pendekatan penelitan yang ditujukan untuk mendeskripsikan dan menganalisis fenomena, peristiwa, aktivitas sosial, sikap, kepercayaan, persepsi, pemikiran orang secara individual maupun kelompok (Nana Syaodih Sukmadinata, 2012: 60).

Sumber data pada penelitian ini, dikelompokkan menjadi dua yaitu: sumber data primer dan sumber data skunder. Sumber data primer adalah sumber data yang dikumpukan langsung dari tangan pertama, yang terdiri dari kepala sekolah/madrasah, dan personalia. Adapun suber data skunder adalah sumber data yang diambil dari objek pendukung seperti dokumentasi yang di Madrasah Ibtidaiyah NW No.I Boro' Tumbuh. Sedangkan teknik pengumpulan data yang digunakan meliputi tiga teknik, yaitu Wawancara secara mendalam (in-depth interviewing), Dermawan Wibisono (20I3 : II8) mengatakan bahwa wawancara adalah komunikasi langsung dimana pewawancara berada dalam situasi beratap muka dan melakukan proses Tanya jawab secara langsung dengan responden. Selain itu juga menggunakan observasi dan dokumentasi.

\section{Hasil dan Pembahasan}

\section{A. Penerapan Manajemen Personalia di MI NW No.1 Boro' Tumbuh}

Manajemen personalia adalah manajemen yang menitik beratkan perhatiannya kepada personel atau kepegawaiaan (keseluruhan orang-orang yang bekerja pada suatu organisasi). Maka keprofesionalisme personalia merupakan salah satu syarat utama dalam mewujudkan keberhasilan pengembangan manajemen personalia. Adapun yang menjadi sebuah alasan mengapa peningkatan profesionalisme tenaga pendidikan dan tenaga kependidikan itu sangat penting, yang mana dikarenakan oleh pesatnya kemajuan perkembangan ilmu pengetahuan dan teknologi. Oleh karena itu sebagai seorang professional diharapkan tenaga pendidik dan tenaga kependidikan di lembaga dapat memehami dan mengatisipasi kemajuan teknologi dalam penerapan manajemen personalia (Suprno Eko Widodo, 20 I I : 65)

Sebagaimana yang dikatakan oleh Hariadi, S.Ag penerapan manajemen personalia yang $d i$ Madrasah Ibtidaiyah NW No.I Boro' Tumbuh ini, memang masih perlu ada perbaikan lagi, hal ini dikarenakan tuntun zaman (wawancara dengan Kepala Madrasah tanggal 7 Februari 2018). Sedangkan menurut para guru, pelaksanaan manajemen personalia sudah lumayan bagus (wawancara dengan Guru Qur'an Hadist Hj. Huddusiah, S.Pd.I tanggal 7 Februari 2018).

Dari pernyataan inform diatas, dapat dikatakan bahwa semangat kemajauan dan perkembangan yang diupayakan dalam membenahi manajemen personalia di Madrasah Ibtidaiyah NW No.I Boro' Tumbuh sangat tinggi. Dari hasil observasi memang di Madrasah Ibtidaiyah NW No.I Boro' Tumbuh ini memberikan ruang gerak atau keterbukaan bagi siapa saja yang ingin meminta informasi mengenai sekolah/madrasah tersebut, telebih sekali bagi para pemerhati kelembagaan pendidikan yang ingin melakukan penelitian, sekolah/madrasah ini selalu membuka pintu untuk hal semacam ini. 


\section{B. Perencanaan Pegawai di MI NW No.I Boro' Tumbuh}

Setiap sekolah/madrasah harus mempunyai rencana pengembangan. Rencana pengembangan sekolah/madrasah merupakan rencana yang komprehensif untuk mengoptimalkan pemanfaatan segala sumber daya yang ada dan yang mungkin diperoleh guna mencapai tujuan yang diinginkan dimasa yang akan datang. Begitu pula dalam perencanaan pegawai merupakan sebuah keharusan yang mutlak, hal ini sebagai gambaran masa depan dari sosok intitusi sekolah/madrasah yang dikehendaki oleh warganya.

Manajemen pendidikan merupakan alternatif strategis untuk meningkatkan kualitas pendidikan. Manajemen sekolah/madrasah secara langsung akan mempengaruhi dan menentukan efektif tidaknya kurikulum, berbagai peralatan belajar, waktu mengajar, dan proses pembelajaran. Berdasarkan hasil observasi yang peneliti lakukan bahwa perencanaan dari manajemen personalia memang harus di perbaiki lagi. Sebagaimana yang dijeaskan oleh Hariadi, "sebagaimana yang saya katakana tadi, manajemen kita ini masih perlu ditingkatkan lagi, baik hal yang mengenai perencanaan sampai kepada penilaian, memang disini kami memiliki target yang harus dicapai oleh para pegawai atau guru, dimana harus mencapi standar minimal $100 \%$ (wawancara tanggal 7 februari 2018).

Dari pernyataan ini dijelaskan bahwa perencanaan manajemen personalia belum begitu sempurna jadi perlu adanya penataan ulang tentang manajemen tersebut. Pengetahuan dan pemahaman yang kurang tentang penerapan manajemen personalia membuat para pegawai akan sulit melaksanakan tugasnya padahal untuk menjadikan manajemen yang baik harus terlebih dahulu memahami tahap apa saja yang harus dilakukan.

Jadi Kemajuan suatu bangsa sangat tergantung pada kemajuan kualitas pendidikan. Kemajuan pendidikan yang baik tersebut tidak mudah untuk dilaksanakan apabila para pengelolah pendidikan kurang memperhatikan tata cara manajemen yang baik dan tidak memikirkan bagaimana pendidikan kedepan agar lebih baik, atau dapat dikatakan hanya melaksanakan peraturan serta tata cara manajemen yang sudah ada tanpa mau berusaha mencari terobosan kedepan.

\section{Rekrutmen Pegawai di MI NW No.I Boro' Tumbuh}

Rekrutmen pegawai adalah menyediakan calon pegawai yang betul-betul siap, yang memenuhi kualifikasi untuk sebuah posisi. Adapun langkah-langkah yang lakukan oleh kepala Madrasah Ibtidaiyah NW No.I Boro' Tumbuh dalam Rekrutmen pegawai, kata bapak kepala sekolah/Madrasah "dalam rekrutmen pegawai, yang penting seorang pelamar itu miliki ijazah SI, kemampuan, etikanya baik dll, itu yang menjadi prioritas kami, dan tidak harus standar PGMI. Sendangkan langkah-langkah kami dalam rekrutmen pegawai ini, pertama, pelamar mengajukan surat lamarannya kepada kepala sekolah/madrasah, setalah ini kepala sekolah/madrasah bermusyawarah kepada pegawai yang lain untuk menguji kelayakan, dan setelah di setuji baru akan diajukan kepada pengurus yayasan (wawancara tanggal 7 Februari 2018).

Melihat pernyataan tersebut prosesi perekrutmen pegawai di Madrasah Ibtidaiyah NW No.I Boro' Tumbuh ini munjukkan hal yang seharusnya dilakukan oleh setiap instansi sekolah/madrasah. Akan tetapi dari hasil wawancara dari KTU (bapak Huzai, S.Pd.I) dalam rekrtumen pegawai memang masih bersifat adanya hubungan keluarga, akan tetapi hal ini tidak menutup mata dalam kemampuan atau kelayakannya, dan hal ini bukan termasuk KKN, Cuma sipat publikasinya selinggup keluarga dekat, tidak secara umum (wawancara tanggal 7 Februari 2018).

Dari penjelasan kepala Madrasah dan guru di atas, bahwa untuk mencari pegawai memang harus melalui berbagai macam seleksi sebagaimana dicontohkan oleh beliau bisa menggunakan wawancara dengan menanyakan berbagai macam hal yang berhubungan dengan pekerjaan maupun pengalamannya serta melihat dokumentasi - dokumentasi lamaran, dan tanpa menggunakan tes tertulis. Sebagaimana yang dikatan oleh bapak kepala sekolah/madrasah "untuk mengetahui kelayakan calon pegawai yang memasukka 
n lamarannya cukup kita mendengangar jawaban sewaktu wawancara, dan saya rasa sudah cukup untuk mengetahui kelayakan, serta dokumentasi waktu lamaran, dan adapun penempatannya sama saja (wawancara tanggal 7 Februari 2018).

Beberapa keterangan di atas dapat di simpulkan bahwa rekrutmen itu sangat mendukung dalam proses manajemen personalia karena dengan melakukan rekrutmen pegawai dari proses kelayakan menjadi penting karena memungkinkan perubahan yang baik dalam manajemen personalia di Madrasah Ibtidaiyah NW No.I Boro' Tumbuh.

\section{Meningkatkan dan Pengembangan Pegawai di MI NW No.I Boro' Tumbuh}

Pendidikan guru adalah bagian integral sistem pendidikan nasional dan merupakan usaha sadar dan berencana bagi pengadaan guru sebagai kunci dalam proses pelaksanaan pendidikan nasional serta sebagai pelaksana langsung dalam proses pendidikan dan mempunyai peranan yang amat penting sehingga mendapat perhatian khusus. Masalah guru dan tenaga kependidikan lainnya, yang meliputi soal pengadaan, pengangkatan dan penyebaran, pembinaan jenjang karier, status dan kesejahteraan hal itu harus ditangani secara menyeluruh dan terkoordinasi.

Untuk ini diperlukan kerjasama yang efektif antar sesama pegawai dalam menghadapi masalah-masalah yang ada, sejalan dengan itu etika guru dan organisasi profesi guru perlu dibina dan dikembangkan juga (Faud Ihsa, 1995 : 25). Adapun peran utama manajer pengembangan sumber daya manusia adalah membantu karyawan dalam mendapatkan pengetahuan dan keterampilan yang mereka butuhkan untuk melakukan pekerjaan, baik yang dilakukan dimasa kini maupun dimasa yang akan datang (Marwansyah, 2010 : I57).

Bapak kepala sekolah/madrasah menjelaskan bahwa "dalam membina dan mengembangkan pegawai, kami berupaya dari mengikutkan para pegawai untuk pelatihanpelatihan yang sekiranya memberikan pembinaan dan pengembangan pegawai kami, dan lain-lainnya. Dan perencanaan kedepan kami akan mengupayakan adanya penyeratatan
PGMI bagi seluruh pegawai kami ini (Wawancara tanggal I0 Februari 2018).

Dari pernyataan tersebut dapat di simpulkan bahwa, keinginan kepala sekolah/madrasah dalam pembinaan dan pengembangan pegawainya sangatlah beliau perhatikan. Berkaitan dengan ini juga hasil wawancara dari pengajar/Guru PNS (Ibu Bardiah, S.Pd.I) mengatakan: "upaya kepala sekolah/madrasah sangat bagus sekali dalam menopang karir kami, misalkan, kitika ada tes CPNS beliau malah menganjurkan untuk mengikuti yang meskipun nantinya kalau lulus harus pindah. Begitulah bapak kepala sekolah/madrasah kami kalau urusan karir sangat mendukung. Begitupula ketika sertifikasi dan infasing guru, beliau langsung mengesahkan, ketika sudah mencukupi masa pengabdian (wawancara tanggal I0 Februari 2018). Melihat dari pernyataan pengajar diatas dapat di pahami, upaya kepala sekolah/madrasah dalam menata karir pegawaipegawainya sangat tinggi, serta memberikan ruang untuk maju bersama-sama.

\section{E. Promosi dan Mutasi di MI NW No.I Boro' Tumbuh}

Promosi dan mutasi ialah terjadi bila seorang pegawai dipindahkan dari sebuah jabatan keposisi lain dengan gaji, tanggung jawab, dan jenjang organisasi yang lebih tinggi, untuk mutasi ia kejenjang organisasi yang relatif sama.

Adapun dari observasi yang peneliti temukan bahwa promosi belum pernah dilakukan, sedangkan untuk mutasi sudah perna terjadi di Madrasah Ibtidaiyah NW No.I Boro' Tumbuh itu dengan sistem Roling, sebagaimana senada dengan apa yang di jelaskan oleh Hariadi, S.Ag, yakni menyatakan "kalau masalah promosi dan mutasi memang belum pernah ada di Madrasah Ibtidaiyah NW No.I Boro' Tumbuh ini, hanya saja mutasi pernah dilakukan dengan sistem Roling, umpamanya, guru kelas I di pendahkan ke kelas 3, iya Cuma itu kalau mengenai hal mutasi” (wawancara tanggal I0 februari 2018).

Jadi kesimpulannya proses mutasi tenaga kerja dari status semula ke status yang lain dapat terjadi karena keinginan tenaga kerja maupun kebijakan manajemen tenaga kerja. 
Baik mutasi atas dasar keinginan tenaga kerja sendiri maupun keinginan manajemen umumnya memiliki tujuan yang pasti, yakni untuk pembinaan dan pengembangan tenaga kerja yang menjadi tanggung jawab manajemen. Disadari bahwa tenaga kerja merupakan salah satu unsur terpenting dari lembaga yang harus dibina dan dikembangkan. Biasanya hasrat dan keinginan tenaga kerja untuk mutasi dari satu bagian ke bagian lain terutama disebabkan tenaga kerja merasa kurang mampu bekerja sama atau karena tugas dan pekerjaannya kurang sesuai dengan kualifikasi, kondisi fisik, dan keinginan yang diharapkannya.

\section{F. Pemberhentian Pegawai di MI NW No.I Boro' Tumbuh}

Menurut Undang-undang No. I3

Tahun 2003 mengartikan bahwa Pemberhentian atau Pemutusan hubungan kerja adalah pengakhiran hubungan kerja karena suatu hal tertentu yang mengakibatkan berakhirnya hak dan kewajiban antar pekerja dan lembaga. Sedangkan menurut Moekijat mengartikan bahwa Pemberhentian adalah pemutusan hubungan kerjas seseorang pegawai dengan suatu organisasi di lembaga. Adapun pemberhentian atau pemutusan hubungan kerja antara suatu lembaga seorang atau beberapa orang pegawai, dapat digolongkan atas tiga sebab utama yaitu : a) karena keinginan lembaga, b) karena keinginan pegawai, dan c) karena sebab lain. (M. Manulang, 2006 : 197).

Dan sebagaimana dijelaskan oleh bapak kepala Madrasah Ibtidaiyah NW No.I Boro' Tumbuh bahwa pemberhentian pegawai sudah pernah terjadi, hal ini dikarenakan usia pensiun, dan ada juga pelanggaran etika. Sebagaimana yang diungkapkan dalam wawancara "pemeberhentian pegawai disini memang pernah terjadi, umpamanya karna pensiun, dan pelanggaran etika, dalam pelanggaran etika ini terjadi pada bulan januari 20I4" (wawancara tanggal I0 Februari 2018).

Dari penjelasan diatas, yang dimaksud dengan pelanggaran etika sebagaimana penelit pahami dari penjelasan inform adalah terbagi menjadi dua hal yakni ada yang bersifat khusus dan ada yang bersifat umum. Adapun yang bersifat khusus diantaranya: agama, tanggung jawab, kesopanan, ketoladanan dan lain-lain.
Sedangkan etika yang bersifat umum diantaranya: kinerja dalam proses pembelajaran, hubungan dengan pegawai yang lain, dan lainlain. Jadi proses Pemberhentian pegawai, hanya bersifat pada pelanggaran etika yang merupakan peraturan yayasan pusat. Sehingga dalam proses pemberhentian pegawai tersebut menjadi peringatan bagi pegawai yang lainnya.

\section{G. Penilaian Pegawai di MI NW No.I Boro' Tumbuh}

Istilah penilaian atau evaluasi berasal dari bahasa inggris yaitu evaluation yang berarti penentuan nilai atau serangkai penilaian. Penilaian adalah suatu tindakan atau proses untuk menentukan nilai dari pada sesuatu (Anwar Syaiful, I995 : 209). Pada umumnya orang-orang yang berkecimpung dalam manajemen sumber daya manusia sependapat bahwa penilaian ini merupakan bagian penting dari seluruh proses kerja pegawai yang bersangkutan. Karena penilaian tersebut berperan sebagai umpan balik tentang berbagai hal seperti kemampuan, kelebihan, kekurangan, dan potensi yang pada gilirannya bermanfaat untuk menentukan tujuan, jalur, rencana dan pengembangan karir.

Bagi lembaga sendiri, hasil penilaian tersebut sangat penting, artinya peranannya dalam pengambilan keputusan tentang berbagai hal, seperti identifikasi kebutuhan program pendidikan dan pelatihan, rekruitment, seleksi, program pengenalan, penempatan, promosi, sistem imbalan dan berbagai aspek lain dan proses dari manajemen sumber daya manusia secara efektif. Guru yang professional adalah guru yang memiliki keahlian sebagai guru. Keahlian yang mana tidak dimiliki oleh profesi manapun juga selain profesi guru. Karena itu, sebagai suatu profesi tentulah harus memenuhi berbagai persyaratan khusus, sebagaimana seorang dokter atau seorang insinyur, dan lain-lain. Seorang guru tidak hanya harus memenuhi berbagai kualifikasi, baik kepribadian, kemampuan mengajar, penguasaan spesialisasi dalam disiplin pada bidang tertentu, tetapi juga haus memiliki kemampuan dalam rangka pembinaan dan pengembangan dari segi manajemen manapun (Oemar Hamalik, 1990 : 2I). 
Dalam mewujudkan tingkat ke fropesionalan pegawai, sebagaimana hasil observasi, ternyata kepala sekolah memili Rapot guru, yang berisi 8 aspek penilaian, diantaranya (Dokumentasi tanggal I2 Februari 2018) :

Tabel I

Format Penilaian Guru di Madrasah Ibtidaiyah NW No.I Boro' Tumbuh

\begin{tabular}{|l|l|l|}
\hline Aspek Penilaian & $\begin{array}{c}\text { Nilai } \\
\text { Kuanti }\end{array}$ & $\begin{array}{c}\text { Nilai } \\
\text { Kuali }\end{array}$ \\
\hline 1. Silabus dan & & \\
Proses & & \\
2. Rencana & & \\
Pelaksanaan & & \\
Pembelajaran & & \\
3. Pelaksanaan & \\
Proses & \\
Pembelajaran & \\
4. Penilaian Hasil & \\
Belajar & \\
5. Pengelolaan & \\
Kelas & \\
6. Administrasi & & \\
Guru & & \\
7. Kepribadian dan & & \\
Sosial & & \\
8. Kedisiplinan & & \\
\hline
\end{tabular}

Dari 8 aspek diatas selanjutnya ada standar penilaian Guru yaitu sebagai berikut (dokumentasi, tanggal I2 Februari 2018):

Tabel II

Standar Penilaian Guru di Madrasah Ibtidaiyah NW No.I Boro' Tumbuh

\begin{tabular}{|r|c|l|}
\hline POIN & NILAI & \multicolumn{1}{|c|}{ KET } \\
\hline $91-100$ & A & $\begin{array}{l}\text { Kelompok } \\
\text { sangat baik }\end{array}$ \\
\hline $81-90$ & A- & $\begin{array}{l}\text { Kelompok } \\
\text { baik }\end{array}$ \\
\hline $71-80$ & B+ & B \\
\hline $61-70$ & &
\end{tabular}

\begin{tabular}{|l|c|l|}
\hline $51-60$ & B- & \\
\hline $41-50$ & C+ & $\begin{array}{l}\text { Kelompok } \\
\text { cukup }\end{array}$ \\
\hline $31-40$ & C & \\
\hline $21-30$ & C- & \\
\hline $11-20$ & D+ & $\begin{array}{l}\text { Kelompok } \\
\text { kurang }\end{array}$ \\
\hline $1-10$ & D & \\
\hline
\end{tabular}

Jadi kesimpulannya seorang manajer mencoba untuk meningkatkan kinerja seorang personalia dimasa yang akan datang. Melalui data pengamatan dan tertulis. Sehingga diharapkan kemajuan lembaga tersebut.

\section{H. Kompensasi di MI NW No.I Boro' Tumbuh}

Kompensasi merupakan salah satu tantangan yang harus dihadapi manajemen. Manajer harus ekstra hati-hati menghadapi masalah ini karena sangat sensitif, terkadang para pegawai juga mempunyai kecendrungan serba kurang dan suka membandingkan kelebihan kesejahteraan yang di berikan lembaga pendidikan lain. Sementara itu, dalam hal-hal tertentu minimnya kesejahteraan dalam lembaga lain tidak pernah membandingkan dengan kelebihan di lembaga sendiri.

Kompensasi atau kesejahteraan yang terjadi pada pegawai di Madrasah Ibtidaiyah NW No.I Boro' Tumbuh tidak dipermasalahkan sebagaimana yang dinyatakan oleh kepala sekolah/madrasah "sistem yang kompensasi kami di Madrasah Ibtidaiyah NW No.I Boro' Tumbuh ini, jadi sebelumnya kami mengadakan musyawarah kesepekatan antra pegawai mengenai kompensi yang berupa materi (wawancara tanggal I2 Februari 2018).

Adapun penjelasan para guru tentang kompensi berupa materil ini, sebagaimana yang dikatakan oleh Huzai, S.Pd.I "mengenai kompensi materil kurang imbang, akan tetapi hal ini bukanlah yang menjadi prioritas utama, melainkan menuangkan amanah pengetahuan, sebagaimana kami dituntun dalam organisasi 
muhammadiyah, sekolah bukanlah ladang mencari materi, tapi tempat beribadah (wawancara tanggal I2 Februari 2018).

Ajaran dalam Islam, kompensasi atau kesejahteraan mendapat perhatian besar. Kesejahteraan ini tidak hanya bersifat material maupun non material. Kesejahteraan material misalnya, berbentuk uang atau barang, sedangkan kesejahteraan non material berwujud seperti pujian, kecepatan dalam memberi gaji, penghormatan dan sebagainya. Adapun cara pemberian gaji kepada pegawai dalam Islam telah digariskan sesuai dengan sabda Nabi SAW:"Berikan upah kepada pekerja sebelum keringatnya kering". Jika pesan hadits ini diamalkan akan memberikan dampak positif bagi manajemen dan pegawainya.

, sehingga hampir tidak ada waktu luang untuk bersama-sama memikirkan kemajauan sekolah/madrasah sekitarnya (Syaiful Sagala, 2013:38)

Disitiap instansi, pada dasarnya problem memanglah ada yang menghiasi jalannya manajemen personalia. Akan tetapi hal tersebut bisa diantispasi oleh manajer atau kepala sekolah/madrasah. Dalam hal ini sebagaimana hasil wawancara yang dikatakan oleh kepala sekolah/madrasah "problem yang kami hadapi di Madrasah Ibtidaiyah NW No.I Boro’ Tumbuh ini, tidaklah begitu banyak diantranya: keterlambatan guru, lupa mengerjakan tugas, dan lain-lain sebaginya. Akan tetapi untuk mengantisipasi hal tersebut kami membuat kesepakan tertulis yang ditandatangani oleh semua pegawai, yang kemudian dipajang

I. Wajib membudayakan disiplin kerja

2. Wajib taat pada hukum, pancasila, dan UUD I945

3. Dapat menjadi Uswatun Hasanah

4. Wajib menunjukkan sikap santun dan menjaga nama baik sekolah

5. Kehadiran paling lambat pukul 06.45 (06.55)

6. Bagi yang pikit paling lambat pukul 06.30

7. Wajib mengisi daftar hadir

\section{Problem-problem yang dihadapi di MI NW No.I Boro' Tumbuh}

Problem yang dihadapi sekolah/madrasah secara umum antara lain : a) administrasi sekolah/madrasah yang belum dibenahi dengan baik, b) team working sekolah/madrasah yang lemah yaitu sebagian pejabat sekolah/madrasah sulit berkoordinasi dengan para guru dan personal lainnya dalam melaksanakan strategi sekolah/madrasah, c) kurangnya kelengkapan kearsipan sekolah/madrasah, d) kurangnya partisipasi masyarakat terhadap pembangunan pendidikan di daerahnya, e) kurangnya fasilitas dan kelengkapan belajar di kelas, f) dibeberapa daerah rendahnya kualitas SDM dari masyarakat sekitar sekolah/madrasah karena rata-rata tingkat pendidikan masih rendah, dan g) kesibukan masyarakat terdidik di sekitar sekolah/madrasah dalam manajemen aktivitas didalam kantor kami (wawancara tanggal I2 februari 2018).

Dari keterangan bapak kepala tersebut, sangat menarik sekali untuk ditiru sehingga dapat meminimalisir problema yang akan terjadi di sekolah/madrasah yang kita tempati. Berikut ini hasil kesepakatan yang merupakan kemetmen guru dan karyawan Madrasah Ibtidaiyah NW No.I Boro' Tumbuh (Dokumentasi, tanggal I2 Februari 2018), sebagai berikut :

Tabel II

Tata Tertib Guru dan Karyawan di Madrasah Ibtidaiyah NW No.I Boro' Tumbuh

\section{TATA TERTIB \\ GURU DAN KARYAWAN MI NW NO. I BORO' TUMBUH}

8. Pulang minimal pukul I4.00 (I3.00)

9. Guru piket mengupayakan kelas yang kosong dapat diisi

I0. Apabila tidak dapat hadir / tidak tepat waktu, meminta izin kepada kepala sekolah dan menyampaikan tugas kepada guru lain.

II. Mendampingi siswa dalam berbagai kegiatan keagamaan sesuai jadwal

I2. Wajib menyelesaikan tugas adminstrasi sesuai jadwal 


\section{kesepakatan.}

I3. Wajib mengikuti kegiatan-kegiatan yang diadakan sekolah

I4. Profesionalisme kerja diatas kepentingan, keluarga, golongan maupun persahabatan

I5. Wajib meningkatkan kualitas diri dan kualitas kerja

I6. Parker sepeda motor pada tempatnya

17. Saat upacara ketenangan dan kedisiplinan dijaga (06.45)

I8. Bagi yang terlambat wajib mengikuti upacara didepan pintu masuk

19. 4S (senyum, salam, sopan, sapa)

20. Dilarang membuat oposisi didalam organisasi

21. Jika ada permasalahan diselesaikan bersama-sama

\section{Simpulan}

Berdasarkan Hasil Penelitian dan Pembahasan sebagaimana yang telah di ungkapkan pada bagian terdahulu, maka dapat di simpulakan sebagai berikut :

Penerapan Manajemen Personalia secara umumnya di Madrasah Ibtidaiyah NW No. I Boro' Tumbuh bisa dikatakan sudah memumpuni atau dalam keadaan kondisi baik. ,meskipun demikian masih tetap perlu ada peningkatan terus menerus.

Pengetahuan dan pemahaman yang kurang tentang penerapan manajemenpersonalia membuat para pegawai akan sulit melaksanakan tugasnya, padahal untuk menjadikan manajemen yang baik terlebih dahulu harus memahami tahap apa saja yang harus dilakukan.

Proses Rekrutmen Pegawai di Madrasah Ibtidaiyah NW No. I Boro' Tumbuh harus melalui beberapa tahapan, antara lain : Calon Pendidik mengajukan surat lamaran wawancara - Musyawarah dewan guru Keputusan Pengurus Yayasan.

Upaya madrasah dalam meningkatkan dan Pengembangan pegawai sangatlah tinggi, serta memberikan ruang untuk maju bersama-sama, misalnya Info sartifikasi Guru, Impasing, dan PNS.

Promosi dan Mutasi di Madrasah Ibtidaiyah NW No. I Boro' Tumbuh tidak pernah terjadi, hanya saja roling Tugas wali kelas.

Pemberhentian pegawai tidak pernah dilakukan, akan tetapi selalu di sampaikan dan tegaskan oleh bapak Kepala Madrasah terkait dengan aturan sekolah/madrasah.

Penilaian pegawai selalu di lakukan dalam bentuk sepervisi.

Dalam pemberian kompensasi dari pihak sekolah/madrasah selalu diperhatikan, dengan mengusahakan rutin minggu pertama dalam penerimaan amprah.

Untuk mengatisipasi Problem-problem sekolah/madrasah, Madrasah Ibtidaiyah NW No. I Boro' Tumbuh melakukan musyawarah kesepakatan bersama untuk menyusun aturan/tatertib yang kemudian di tempel menjadi meding permanen serta di tanda tangani langsung.

\section{Referensi}

Hamalik, Oemar. (1990). Pengembangan Kurikulum. Bandung : Manar Maju.

Ihsa, Fuad.(1995). Dasar - Dasar Kependidikan, Semarang: Rineka Cifta.

Manulang, M. Dkk. (2006). Manajemen Personalia. Medan: Gadjah Mada Universiti Press.

Marwansyah. (2010). Manajemen Sumberdaya Manusia. Bandung : Alfabeta.

Sagala, Syaiful. (2013). Manajmen Strategi dalam Meningkatkan Mutu Pendidikan. Bandung: Alfabet.

Sukmadinata, Nana Syaodih. (20I2). Metode Penelitian Pendidikan. Bandung : PT Remaja Rosdakarya.

Syaiful, Anwar. Tayar yususf. (1995). Metodologi Pengajaran Agama Dan Bahasa Arab. Jakarta: PT. Raja Grafindo Persada.

Wawancara dengan Guru Mata Pelajaran Qur'an Hadis (Hj. Hudusiah) Madrasah Ibtidaiyah NW No.I Boro' Tumbuh.

Wawancara dengan Kepala Madrasah Ibtidaiyah NW No.I Boro' Tumbuh (Hariadi, S.Ag).

Wawancara dengan KTU (Huzai, S.Pd.I) Madrasah Ibtidaiyah NW No.I Boro' Tumbuh. 
Wawancara dengan PNS (Badariah, S.Pd.I) Madrasah Ibtidaiyah NW No.I Boro' Tumbuh.

Wibisono, Dermawan. (2013). Panduan Penyusunan Skripsi, Tesis \& Disertasi. Yogyakarta : C.V Andi Offset.

Widodo, Suparno Eko. (20II). Manajemen Mutu Pendidikan. Jakarta : PT. Ardadizya Jaya. 